\title{
Perempuan dalam Pendidikan Islam di Kerinci: Sejarah dan Perkembangan Pondok Pesantren Nurul Haq Semurup 1982- 2002
}

\author{
Khirpal Fikri', Saifullah S.A2, Nelmawarni ${ }^{3}$ \\ 1,2,3 Universitas Islam Negeri (UIN) Imam Bonjol Padang \\ e-mail: khirfalfiqri0220@gmail.com
}

\begin{abstract}
ABSTRAK. Kerinci mempunyai sosok perempuan yang berperan di dunia pendidikan Islam yaitu Rafi'ah Karim, Ruqiyah Karim dan Kahdijah Maris. Ketiganya berperan melalui pendirian Pondok Pesantren Nurul Haq Semurup yang didirikan pada tahun 1982. Mereka membagi peran dalam pembangunan pesantren dimana Rafi'ah Karim sebagai pelaksana di lapangan, Ruqiyah Karim sebagai penyuplai dana dan iformasi pesantren, sedangkan Khadijah Maris sebagai pengurus administrasi serta sebagai tenaga pengajar. Peran pesantren Nurul Haq terhadap pendidikan Islam di Kerinci ialah selain sebagai penyedia layanan pendidikan, dalam kurun waktu 1982-2002 pesantren juga berperan di beberapa bidang seperti sosial, keagamaan dan kemasyarakatan, diantaranya sebagai pembuka jalan bagi pesantren-pesantren modern lainnya di Kerinci, bekerja sama dengan ulama setempat untuk perbaikan akhlak masyarakat seperti fenomena kenakalan remaja, konsumsi minuman keras dan judi sabung ayam pada masyarakat sekitar. Melalui kerja sama dengan ulama dan masyarkat sekitar pesantren juga mensosialisasikan penggunaan hijab secara syar'i kepada beberapa golongan masyarakat yang belum mengenakan hijab sesuai ketentuan Islam.
\end{abstract}

Kata kunci: Perempuan, Pendidikan Islam, Pondok Pesantren Nurul Haq Semurup..

\section{PENDAHULUAN}

Eksistensi perempuan dalam pendidikan di Indonesia merupakan suatu tema bahasan yang membutuhkan kajian yang mendalam dan terperinci. Menurut beberapa ahli, semenjak zaman kolonial Belanda keadaan ini semakin parah karena didukung oleh adat istiadat yang meminimkan peran perempuan dalam tatanan sosial masyarakat termasuk pendidikan ${ }^{1}$. Disisi lain, di bidang Pendidikan Islam secara historis, sosiologis dan kultural tidak ditemukan bukti yang kuat tentang adanya diskriminasi dan segregasi kaum perempuan di Indonesia hanya karena posisi mereka sebagai muslimah². Jika ada, hal tersebut terjadi bukan karena status mereka sebagai muslimah, melainkan karena tradisi social dan cultural indigenous lokal. Para muslimah tidak mengalami diskriminasi untuk menempuh pendidikan di lembaga Pendidikan Islam tradisional seperti surau dan sebagainya. Oleh sebab itu bisa kita asumsikan bahwa diskriminasi terhadap perempuan di

\footnotetext{
${ }^{1}$ Ramayulis. 2012. Sejarah Pendidikan Islam, (Jakarta: Kalam Mulia), 414

2 Azyumardi Azra. 2012. Pendidikan Islam: Tradisi dan Modernisasi di Tengah Tantangan Milenium III, (Jakarta: Kencana), 139
} 
bidang pendidikan di Indonesia bukan karena status muslimah seorang perempuan, melainkan karena adat dan sosial masyarakat yang berkembang pada saat itu.

Diskriminasi terhadap perempuan juga terlihat dari bagaimana masyarakat memandang rendah pempuan. Masyarakat cendrung memposisikan perempuan sebagai kaum marginal dan pembagunan sumber daya manusia pada perempuanpun minim dilakukan ${ }^{3}$. Selain itu, tidak jarang juga perempuan dimarginalkan secara structural ${ }^{4}$

Perkembangan Pendidikan Islam Indonesia terutama di Sumatera terjadi setelah adanya pembaharuan pemikiran Islam tahap kedua atau yang lebih popular disebut "gerakan kedua" 5 yang dilakukan oleh kaum muda yang dipelopori oleh Haji Muhammad Jamil Jambek Bukittinggi, Haji Abdullah Ahmad Padang Panjang, Haji Muhammad Taib Umar Sungayang dan Haji Abdul Karim Amrullah Maninjau. Mereka melakukan pembaharuan di bidang keagamaan seperti pemurnian agama dari segala bid'ah atau hal yang bukan berasal dari Rasullah, pembaharuan dengan keharusan berijtihad serta menjauhi kejumudan dalam pemahaman dan pemikiran ajaran agama, selanjutnya modernisasi dalam bidang pendidikan, politik dan social ${ }^{6}$. Pemodrenan di bidang pendidikan Islam terjadi dengan terbentuknya berbagai lembaga pendidikan Islam seperti Adabiyah School di Padang ${ }^{7}$ dan lahirnya Sumatera Thawalib ${ }^{8}$. Pemodrenan pendidikan Islam oleh kaum muda juga membuka peluang bagi para muslimah untuk terlibat lebih dalam pendidikan Islam.

Salah seorang tokoh pendidikan Islam yang lahir di generasi ini ialah Rahmah el Yunusiyyah ${ }^{9}$. Ia merupakan pendiri Al Madrasatul Diniyah atau Melsyes School yang lebih popular dengan nama Diniyah Puteri Padang Panjang pada 1 Nopember $1923^{10}$. Dari Diniyah Puteri ini melahirkan tokoh-tokoh perempuan di berbagai bidang termasuk pendidikan, salah satu yang paling terkenal ialah Hajjah Rangkayo Rasuna Said. Selain itu Diniyah Puteri juga melahirkan tokoh-tokoh perempuan yang berperan dalam pendidikan Islam di Kerinci.

Terdapat tiga orang tokoh perempuan di bidang pendidikan Islam di Kerinci, mereka ialah Rafi'ah Karim, Ruqiyah Karim dan Khadijah Maris. Mereka menempuh pendidikan di Diniyah Puteri Padang Panjang dan berperan dalam pendidikan Islam di Kerinci melalui pendirian dan pengembangan Pondok Pesantren Nurul Haq yang mereka dirikan pada tahun 1982. Melalui pendirian dan pengembangan Pondok Pesantren Nurul Haq Semurup inilah para tokoh tersebut memberikan peran dalam Pendidikan Islam di Kerinci.

\footnotetext{
${ }^{3}$ A. K Nuzuli. 2021. Pelatihan Media Sensitif Gender bagi Penggiat Media Bersama DP3AP2KB Provinsi Jawa Tengah. Jurnal Komunikasi Profesional, 5(3), 294-304

${ }^{4}$ A. K. Nuzuli. 2021. Tinjauan Pelanggaran Kode Etik Jurnalistik dalam Pemberitaan Prostitusi Online di Surabaya. Jurnal Warta Ikatan Sarjana Komunikasi Indonesia. 4(1), 35-43.

${ }^{5}$ Nelmawarni. 2013. Persatuan Tarbiyah Islamiyah, Dari Organisasi Sosial Keagamaan ke Partai Politik, cet I, (Padang: Imam Bonjol Press), 2

${ }^{6}$ B.J.O Schrieke. 1973. Pergolakan Agama di Sumatera Barat, (Jakarta: Bhratara Press), 59

7 Burhanuddin Daya. 1995. Gerakan Pembaharuan Pemikiran Islam Kasus Sumatera Thawalib, cet. II (Yogyakarta: Tiara Wacana), 13

${ }^{8}$ Yulizal Yunus, dkk. 2008. Beberapa Ulama di Sumatera Barat, (Padang: Pemerintah Propinsi Sumatera Barat Dinas Pariwisata Seni dan Budaya UPTD Museum Adityawarman), 191

9 Aminuddin Rasyad. 1991. Rahmah El Yunusiyah, Zainuddin Labai El Yunusy, Dua Bersaudara Tokoh Pembaharu Pendidikan di Indonesia, (Jakarta: Pengurus Diniyah Putri Perwakilan Jakarta), 41

${ }^{10}$ Rosniati Hakim. [tt]. Pendidikan Sumatera Barat Berwawasan Gender: Lintas Sejarah Tahun 18901945, Kaafah: Jurnal Ilmiah Kajian Gender, 213
} 


\section{METODOLOGI}

Penelitian ini ialah penelitian sejarah, dalam merekontruksi sejarah, setidaknya ada tiga komponen penting yaitu pelaku sejarah (manusia), peristiwa yang terjadi dan waktu. ${ }^{11}$ Dalam kajian yang dibahas menjadikan ketiga tokoh perempuan dalam Pendidikan Islam di Kerinci serta Pondok Pesantren Nurul Haq sebagai objek penelitian. Sumber-sumber yang digunakan ialah sumber primer seperti arsip-arsip pesantren seperti akta notaris yayasan, brosur, akta tanah pesantren dan dokumen-dokumen lainnya yang berkaitan dengan para tokoh perempuan dan pesantren. Sumber selanjutnya ialah buku-buku, jurnal, skripsi, tesis dan disertasi yang berhubungan dengan objek penelitian. Sumber-sumber lisan juga menjadi salah satu sumber dalam penelitian ini dimana para saksi hidup yang melihat dan mengalami langsung apa yang telah dilakukan oleh para tokoh perempuan tersebut dalam pendirian dan pengembangan pesantren kami datangi dan wawancara untuk memperoleh data yang lebih banyak untuk penelitian ini. Selanjutnya sumber-sumber tersebut melalui tahap kritik sumber secara internal dan eksternal untuk mengetahui kebenaran dari sumber-sumber tersebut. Setelah diperoleh informasi melalui sumber tersebut maka selanjutnya akan di interpretasi dengan menformulasi data yang ada menjadi sebuah rangkaian peristiwa yang terjadi pada para tokoh perempuan di Kerinci. Tahap terakhir ialah penulisan, yaitu menuliskan hasil penelitian ke dalam bentuk karya ilmiah. ${ }^{12}$

\section{HASIL DAN PEMBAHASAN}

\section{Dinamika Pendidikan Islam di Kerinci}

Pendidikan Islam modern di Kerinci mulai marak dan menampakkan geliaknya pada awal abad $20^{13}$, pada saat itu banyak pelajar Kerinci yang menuntut ilmu ke luar seperti ke daerah Minangkabau seperti Tarbiyah Islamiyah di Canduang yang didirikan oleh Syeikh Sulaiman Ar Rasuli dan bahkan sampai ke Timur Tengah. Setelah kepulangan mereka, terutama para pelajar yang belajar di Minagkabau, mulai berdiri madrasah-madrasah diantaranya, Modern Islamiyah oleh Abdurrahman Dayah, Madrasah Tsanawiyah oleh Adnan Tayib dan Madrasah Tuwailib di Rawang oleh M. Khatib. Namun madrasahmadrasah ini masih memiliki corak pendidikan sebelumnya yaitu berbentuk halaqah. Madrasah-madrasah di Kerinci banyak didirikan oleh para ulama Kerinci alumni Tarbiyah Islamiyah di Candung, Bukit Tinggi.

Selain itu pada tahun 1945 Muhammadiyah mulai hadir di Kerinci dan bergerak dalam memadukan pendidikan umum dengan Islam. Hal ini menjadi wadah bagi ulamaulama Kerinci yang beraliran kaum muda Minangkabau untuk mengembangkan pendidikan Islam sesuai dengan pola fikir mereka.

Beberapa lembaga pendidikan Islam yang berkembang di Kerinci setelah masa kemerdekaan baik bercorak kaum tua ataupun kaum muda diantaranya ialah madrasah di Koto Petai dan di Hiang pada tahun 1950, berdirinya PGA 4 tahun oleh pemerintah pada tahun 1960, tahun 1963 berdiri Fakultas Syari'ah Muhammadiyah yang didirikan oleh Abdullah Arifin, Adnan Tayib dan Dawud Kohiri. Selanjutnya pada tahun 1965 berdiri

\footnotetext{
11 Jamal Mirdad \& Rahmat, S. 2021. SEJARAH DALAM PERSPEKTIF ISLAM. El-Hekam, 6(1), 9-
}

12 Irhash A. Shamad. 2003. Ilmu Sejarah, (Jakarta: Hayfa Press)

13 Martunus. 2009. "Pemikiran Kalam Ulama Kerinci dan Implementasinya dengan Etos Kerja", Tesis Pascasarjana LAIN Imam Bonjol Padang, 21 
PGA 6 tahun dan peralihan Fakultas Syari'ah Muhammadiyah menjadi negeri, PGA A juga didirikan di Kerinci dibawah pimpinan Abdul Aziz pada tahun 1967.

Pada tahun 1970-an masih terdapat banyak madrasah yang dipimpin oleh ulamaulama lulusan Tarbiyah Islamiyah. Tercatat sebanyak 20 madrasah masih aktif pada tahun 1970 di Kerinci (Statistik Sekolah dan Madrasah di Kerinci 1970-1991 oleh Kementerian Agama Kabupaten Kerinci). Namun hal ini tidak bertahan lama karena pada era tersebut pula pemerintah memberlakukan kebijakan penyeragaman sistem sekolah madrasah yang seluruhnya akan dilebur ke dalam PGA 4 tahun dan PGAN 6 tahun. Tercatat beberapa buah madrasah di Kerinci meleburkan diri kedalam PGAN seperti Madrasah Jamiatu Thuwalib pimpinan Burkhan Saleh pada tahun 1972 di Tanjung Pauh. Keputusan ini diambil karena demi mendapatkan fasilitas dan sertifikat lulusan yang dapat bekerja di instansi pemerintah khususnya Departemen Agama. Disamping itu juga terdapat beberapa ulama yang menolak madrasahnya dilebur ke dalam PGAN seperti madrasah di Koto Petai. Penolakan ini didasari oleh idealisasi ulama yang mengelola madrasah tersebut untuk tidak beralih menjadi bagian dari kepentingan pemerintah serta lebih lanjut khawatir nantinya sistem pendidikan yang telah mereka terapkan sebelumnya akan berubah total.

Beberapa madrasah bahkan terpakasa ditutup karena kebijakan pemerintah tersebut. Karena menolak visi dan misi pemerintah tersebut berimbas kurangnya daya saing mereka dalam menarik minat para pelajar untuk belajar di madrasah yang mereka dirikan, contohnya ialah Madrasah as Shibyan pimpinan H. ilyas di Hiang yang harus tutup karena alasan tersebut.

Keadaan ini kemudian di perparah dengan kebijakan pemerintah yang mengangkat para ulama menjadi pegawai pemerintah, walaupun tidak semua ulama menerimanya. Disamping itu, kebijakan pemerintah untuk mendirikan Madrasah Ibtidaiyah Negeri (MIN) dan Madrasah Ibtidaiyah Swasta (MIS) menyebabkan madrasah atau pengajian para ulama menjadi sepi dari pelajar yang belajar Al Quran dan kitab kuning lainnya. Keberadaan MIN dan MIS yang memiliki fasilitas layaknya sekolah dasar menjadi alasan utama hal tersebut terjadi.

Akhirnya pada tahun 1985 hanya tinggal 1 madrasah bercorak lama yang masih aktif yaitu madrasah Mukhtariyah di Ambai. Madrasah ini juga hanya bertahan beberapa tahun, sebelumnya akhirnya berubah menjadi Pondok Pesantren Modern Mukhtariyah Ambai yang telah memiliki mata pelajaran umum.

\section{Perempuan Dalam Pendidikan Islam di Kerinci}

Pada tahun 1982, muncul 3 orang tokoh perempuan di Kerinci yang terjun ke dunia Pendidikan Islam dengan mendirikan dan mengembangkan sebuah lembaga Pendidikan Islam yang bernama Pondok Pesantren Nurul Haq Semurup. Ketiga perempuan ini ialah Rafi'ah Karim, Ruqiyah Karim dan Khadijah Maris. Ketiganya merupakan alumni Diniyah Puteri Padang Panjang yang memang memiliki cita-cita pendidikan yaitu : "Melaksanakan Pendidikan dan Pengajaran berdasarkan ajaran Islam dengan tujuan membentuk putri yang berjiwa Islam dan Ibu pendidik yang cakap, aktif dan bertanggung jawab tentang kesejabteraan masyarakat dan tanah air dalam pengabdian kepada Allah SWT. ${ }^{14}$

14 Abdullah Nafila. 2016. Rahmah el-Yunisiyyah Kartini Padang Panjang, Sosiologi Agama: Jurnal Ilmiah Sosiologi Agama dan Perubahan Sosial, 10(2), 54 
Pendirian Pondok Pesantren Nurul Haq oleh ketiganya di dasari oleh keinginan mereka untuk mengamalkan ilmu yang mereka miliki serta untuk meneruskan cita-cita Haji Abdul Karim untuk medirikan sebuah lembaga Pendidikan Islam Modern di Kerinci. Hasil diskusi ketiganya melahirkan keputusan untuk mendirikan sebuah lembaga Pendidikan Islam Modern di Kerinci berbentuk Pesantren. Salah satu alasan di pilihnya pesantren sebagai bentuk lembaga pendidikan Islam yang mereka bangun di karenakan posisi Ruqiyah yang pada saat itu berkeja di Kementerian Agama. Mengingat mulai tahun 70-an perubahan dan perkembangan pesantren sangat pesat terjadi di Indonesia.

Semakin meningkatnya kuantitas pesantren di berbagai daerah di Indonesia baik di pedesaan, pinggiran kota maupun di perkotaan dan adanya tingkat keberagaman dan orientasi pimpinan pesantren dan independensi pimpinannya yang memperkuat argumentasi bahwa pesantren merupakan lembaga pendidikan swasta yang mandiri yang merupakan lembaga pendidikan berbasis masyarakat. Alamsyah Ratu Prawiranegara juga mengatakan bahwa Ki Hajar Dewantara menyatakan bahwa pondok pesantren merupakan dasar pendidikan nasional, karena sesuai dan selaras dengan jiwa dan kepribadian bangsa Indonesia $^{15}$. Atas dasar keberadaannya di Kementerian Agama inilah Ruqiyah mengambil keputusan tersebut. Hubungan kedekatannya dengan Alamsyah Ratu Prawiranegara juga ikut mempengaruhi keputusannya tersebut.

Pada 2 Agustus 1982 berdirilah sebuah lembaga pendidikan Islam yang di beri nama Pondok Pesantren Nurul Haq yang berlokasi di Desa Air Tenang Semurup Kecamatan Air Hangat Kabupaten Kerinci Provinsi Jambi. Pondok Pesantren Nurul Haq berdiri dengan struktur sebagai berikut, Dewan Pendiri terdiri dari Rafi'ah Karim, Ruqiyah Karim, Khadijah Maris dan H. Nancik. Pimpinan pesantren saat itu di duduki oleh Rafi'ah Karim dibantu oleh sekretaris Azharuddin K, perlengkapan oleh Suhatrir Karim dan sebagai pelindung yaitu H. M. Dinar.

Dalam operasionalnya, ketiga tokoh perempuan ini memiliki peran di sector masing-masing dalam pengembangan lembaga Pendidikan Islam yang mereka dirikan ini. Rafi'ah Karim berperan sebagai pelaksana langsung dimana ia menjabat sebagai Pimpinan dan juga sebagai tenaga pengajar. di sisi lain Ruqiyah Karim bertindak sebagai penyedia kebutuhan materil dan informasi bagi pesantren karena keberadaannya di Kementerian Agama Pusat. Sedangkan Khadijah Maris mengurus administrasi dan perbendaharaan pesantren, di samping juga sebagai salah satu tenaga pengajar di pesantren.

Di awal berdirinya pesantren ini, respon yang diberikan masyarakat cukup baik namun belum sepenuhnya memberikan respon dan dukungan yang bisa membuatnya berkembang lebih lanjut. Hal ini dikarenakan adanya hambatan dibidang prasarana pondok pesantren. mengingat pada dua tahun pertama setelah berdirinya pesantren, prasaran yang tersedia hanyalah sebuah gedung dua tingkat yang terdiri dari enam ruang belajar. Prasarana ini tidak cukup optimal untuk mendukung minat pelajar pada waktu itu dan menjadi penghambat untuk perkembangan pesantren lebih lanjut. Rafi'ah lalu menyampaikan masalah ini kepada Ruqiyah dan untuk menyelesaikan permasalahan ini Ruqiyah lalu mencari solusinya. Hubungan baiknya di lingkungan Kementerian Agama saat itu akhirnya menghadirkan solusi bagi permasalahan yang dihadapi oleh pondok pesantren dengan

\footnotetext{
15 Alamsyah Ratu Prawiranegara. 1982. Pembinaan Pendidikan Agama, (Jakarta: Depag RI), 41
} 
mendapatkan bantuan untuk pembangunan prasarana pondok pesantren dari Kementerian Agama.

Dengan bantuan tersebut maka dibangunlah tambahan gedung baru, satu Masjid dan satu unit asrama yang dapat menampung lebih kurang 100 santri. Pada tahun 1984 pembangunan prasarana baru tersebut akhirnya rampung dan diadakanlah acara peresmian yang saat itu diresmikan langsung oleh Menteri Agama RI saat itu yaitu H. Alamsyah Ratu Prawiranegara.

Dari segi peningkatan kualitas pembelajaran Pendidikan Islam, salah satu langkah yang dilakukan ketiganya ialah menjalin kerja sama dengan Mesir melalui Kementerian Agama untuk mendatangkan tenaga pengajar dari Mesir guna meningkatkan kualitas pengajaran Bahasa Arab dan pelajaran agama lainnya. Program ini dimulai pada tahun 1989 dimana pada saat itu datanglah tenaga pengajar dari Mesir yang bernama Prof. Muhammad Ismail al-Athar yang menetap dan mengajar di Pondok Pesantren Nurul Haq selama empat tahun dari kurun waktu 1989 hingga 1993. Setelah habis masa kontraknya lalu digantikan oleh Muhammad Hasan al-Ali pada periode 1993 hingga 1995. Pada periode ini jugalah timbul inisiatif para pendiri pesantren untuk membuka satu jenjang pendidikan lanjutan setingkat sekolah menengah atas yang akhirnya berdiri pada tahun 1994 yang diberi nama Madrasah Aliyah Nurul Haq. Pendirian ini bertujuan untuk memberi wadah kepada para santri pesantren yang telah menamatkan pendidikan tsanawiyah untuk bisa memperdalam lagi pendidikan yang mereka peroleh sebelumnya. Pada tahun 1995, kontrak pengajar kedua berakhir dan ia pulang ke Mesir untuk seterusnya digantikan oleh Prof. H. Ali Azidin Hasan Ali yang mengajar di pesantren pada kurun waktu 1995 hingga 1997.

Pondok pesantren yang mereka dirikan dan kembangkan ini memiliki pengaruh yang cukup besar dalam di Kerinci. Di bidang pendidikan, dengan kombinasi dua kurikulum yaitu kurikulum nasional dan kurikulum pesantren, pondok pesantren Nurul Haq memberikan opsi yang lebih baik kepada para pelajar di Kerinci yang bertujuan untuk menuntut ilmu agama, namun disisi lain juga tetap mendapat pendidikan formal dan ijazah yang diakui secara nasional. Dengan posisinya sebagai pesantren modern pondok pesantren Nurul Haq telah memberi kontribusi terhadap pendidikan Islam di Kerinci dengan melestarikan pengajaran ilmu-ilmu agama Islam yang tonggak pengajarannya telah ditancapkan oleh ulama-ulama Kerinci di era sebelumnya dan terancam hilang oleh keberadaan sekolah umum yang kian meminimalisir pengajaran agama di lembaga pendidikan tersebut.

Dari sisi kelembagaan, berkembangnya pesantren di Kerinci sedikit banyak merupakan pengaruh dari keberhasilan pondok pesantren Nurul Haq dalam membuktikan kepada masyarakat Kerinci yang notabene pada awal pasca kemerdekaan lebih cenderung kearah Kaum Tua karena berkembangnya sekolah Tarbiyah Islamiyah di Kerinci pada saat itu bahwa pendidikan Islam bisa merangkul modernitas dan berhasil dalam proses pelaksanaanya tanpa kehilangan identitas ke-Islaman. Hal ini juga membuktikan bahwa modernisasi sistem pembelajaran merupakan salah satu komponen yang menjaga lestarinya lembaga pendidikan Islam di Kerinci, karena lembaga pendidikan tradisonal mulai tergeser oleh pesatnya kemajuan sekolah-sekolah umum yang menawarkan berbagai cabang ilmu di berbagai bidang baik ilmu sosial, eksak dan keterampilan yang dianggap lebih berguna dalam menjalani kehidupan keduniaan di kemudian hari. Posisinya sebagai pondok pesantren modern pertama di Kerinci membuka jalan bagi lembaga-lembaga serupa untuk 
tumbuh di Kerinci. Kemajuan yang dialami oleh pondok pesantren Nurul Haq menimbulkan reaksi berupa hadirnya lembaga-lembaga serupa di berbagai daerah di Kabupaten Kerinci.

Di sisi sosial kemasyarakatan pesantren Nurul Haq bekerja sama dengan masyarakat untuk memberantas beberapa penyakit masyarakat di sekitar pesantren seperti perjudian, kenakalan remaja, konsumsi minuman keras dan sabung ayam yang saat itu banyak terjadi di sekitar pesantren (Ari Saputra. 2011, hlm. 66). Pemakaian kerudung secara Islami juga di sosialisasikan dengan menjadikan para santriwati sebagai teladan bagi masyarakat untuk berbusana secara Islami.

Pondok pesantren Nurul Haq yang didirikan dan di kembangkan oleh ketiga tokoh perempuan ini telah melahirkan banyak alumni yang terjun ke dunia Pendidikan Islam di Kerinci dan member corak dalam perkembangan Pendidikan Islam di Kerinci.

\section{PENUTUP}

Keberadaan tokoh perempuan dalam dunia Pendidikan Islam di Kerinci dapat ditemukan melalui 3 orang tokoh perempuan yang mendirikan dan mengembangkan Pondok Pesantren Nurul Haq Semurup. Mereka ialah Rafi'ah Karim, Ruqiyah Karim dan Khadijah Maris. Usaha dan peran yang mereka lakukan di Pondok Pesantren Nurul Haq Semurup telah banyak memberi nilai positif dalam dunia Pendidikan Islam di Kerinci. Karena hal itulah terlepas dari status gender mereka, sudah sepantasnya mereka di kenal sebagai tokoh Pendidikan Islam yang ada di kerinci.

\section{REFERENSI}

A Shamad, Irhash. 2003 Imu Sejarah, Jakarta: Hayfa Press,

Azra, Azyumardi. 2012. Pendidikan Islam: Tradisi dan Modernisasi di Tengah Tantangan Milenium III, Jakarta: Kencana

Daya, Burhanuddin. 1995. Gerakan Pembaharuan Pemikiran Islam Kasus Sumatera Thawalib, cet. II, Yogyakarta: Tiara Wacana

Hakim, Rosniati, Pendidikan Sumatera Barat Berwawasan Gender: Lintas Sejarah Tahun 1890-1945, Kaafah: Jurnal Ilmiah Kajian Gender

Mirdad, J., \& Rahmat, S. 2021. SEJARAH DALAM PERSPEKTIF ISLAM. ElHekam, 6(1),

Martunus. 2009. "Pemikiran Kalam Ulama Kerinci dan Implementasinya dengan Etos Kerja”, Tesis Pascasarjana IAIN Imam Bonjol Padang.

Nafila, Abdullah. 2016. Rahmah el-Yunisiyyah Kartini Padang Panjang, Sosiologi Agama: Jurnal Ilmiah Sosiologi Agama dan Perubahan Sosial 10(2)

Nelmawarni. 2013. Persatuan Tarbiyah Islamiyah, Dari Organisasi Sosial Keagamaan ke Partai Politik, cet I, Padang: Imam Bonjol Press

Nuzuli A. K. 2021. Pelatihan Media Sensitif Gender bagi Penggiat Media Bersama DP3AP2KB Provinsi Jawa Tengah. Jurnal Komunikasi Profesional, 5(3)

Nuzuli A. K. 2021. Tinjauan Pelanggaran Kode Etik Jurnalistik dalam Pemberitaan Prostitusi Online di Surabaya. Jurnal Warta Ikatan Sarjana Komunikasi Indonesia. 4(1). 
Ramayulis. 2012. Sejarah Pendidikan Islam, Jakarta: Kalam Mulia RI.

Ratu Prawiranegara, Alamsyah. 1982. Pembinaan Pendidikan Agama, Jakarta: Depag

Rasyad, Aminuddin. 1991. Rahmah El Yunusiyah, Zainuddin Labai El Yunusy, Dua Bersaudara Tokob Pembaharu Pendidikan di Indonesia, Jakarta: Pengurus Diniyah Putri Perwakilan Jakarta.

Saputra, Ari. 2021. Peran Pesantren Terhadap Kondisi Sosial Keagamaan di Desa Semurup Kecamatan Air Hangat Kabupaten Kerinci dari Tahun 1982-2002, Skripsi Jurusan Pendidikan Sosiologi-Antropologi Fakultas Ilmu Sosial Universitas Negeri Padang.

Schrieke, B.J.O. 1973. Pergolakan Agama di Sumatera Barat, Jakarta: Bhratara Press.

Yunus, Yulizal dkk. 2008. Beberapa Ulama di Sumatera Barat, Padang: Pemerintah Propinsi Sumatera Barat Dinas Pariwisata Seni dan Budaya UPTD Museum Adityawarman. 